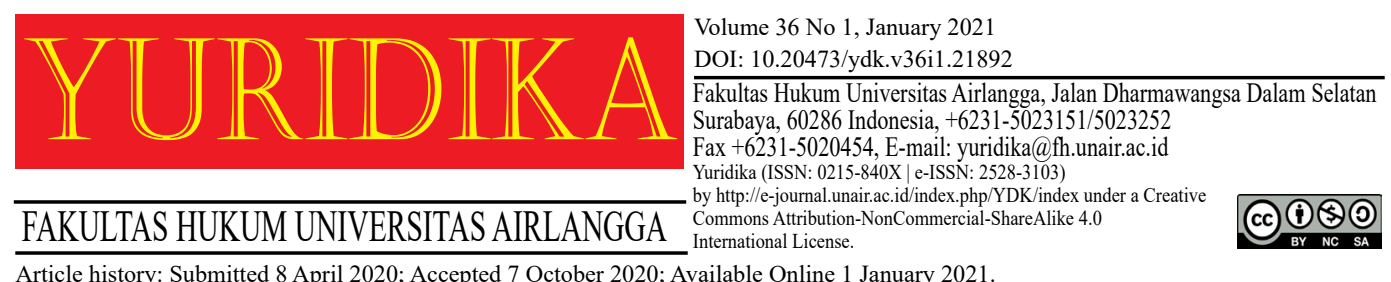

\title{
The Annexation of The General Judiciary Against Consumer Dispute Resolution Agency
}

\author{
Otih Handayani, Agus Riwanto and Panti Rahayu \\ otih.handayani@gmail.com \\ Bhayangakara University of Greater Jakarta, Universitas Sebelas Maret and \\ Bhayangkara University of Greater Jakarta
}

\begin{abstract}
This article aims to analyze the authority of the Consumer Dispute Resolution Agency (BPSK) as Quasi-Judicial in handling consumer disputes as mandated in Article 49 paragraph (1) of Law No. 8 of 1999. This research is a normative legal study that is prescriptive and technical/applied. The research approach uses the Act approach. This legal research material uses primary legal materials and secondary legal materials. The technique of collecting legal materials through library research is then analyzed using qualitative methods. Supervision of the default clause stipulated in the credit agreement is the authority of BPSK; since 2013, the Supreme Court has consistently dismissed consumer disputes for credit agreements positioned as ordinary agreements, stating the parties to the dispute should take their case to the general Judiciary, as well as correcting BPSK's authority. This not only does not imply the principle of lex specialis derogate lex religious but also does not implement efficiency theory that ultimately harms consumers.
\end{abstract}

Keywords: Consumer Dispute Resolution Agency; Authority; Consumer Disputes.

\section{Introduction}

The Covid-19 pandemic has resulted in several countries entering the economic recession phase, including the United States, Germany, France, Italy, South Korea, Hong Kong, Japan, Singapore, the Philippines, and the United Kingdom. ${ }^{1}$ Indonesia will also experience the same thing if it does not immediately leap the strategy of handling health and the economy. This economic situation is certainly closely related to the purchasing power of consumers as an economic

1 Fika Nurul Ulya, 'Ini 10 Negara Jatuh Resesi Akibat Pandemi, Bagaimana Dengan Indonesia?' (Kompas.com, 2020) <https://money.kompas.com/read/2020/08/13/133706626/ini-10-negara-jatuh-resesi-akibat-pandemi-bagaimana-dengan-indonesia?page=all $>$ accessed 20 August 2020 . 
driving force. Consumers have an important role to play in a country's economic activities.

From various walks of life, consumers from middle and lower-income communities are severely affected by the Large-Scale Social Restriction (PSBB) policy in various areas in the form of decreased income because some of those working in the non-formal sector cannot make a living, who work in the formal sector also experience layoffs or are housed by companies. Meanwhile, consumers of upper-middle-income communities also withhold consumption and even tend to save. $^{2}$

Consumers are central to all business activities and are also the only ones subject to all exploitation types. Technological advances and changing consumer expectations have prompted business people to adopt strategies to profit and meet growing competition. This requires serious government action to protect the interests of consumers from ever-increasing exploitation. Another major reason is the lack of awareness among consumers about its rights and protective measures. ${ }^{3}$

In addition to consumers, businesses as spouses of consumers also have an equally important role; often, among them, there are disputes that, if not resolved properly, will harm the national economy. Therefore, regulations are needed that can bridge both parties' interests through Law No. 8 of 1999 on Consumer Protection, which regulates dispute resolution through institutions tasked with resolving disputes between consumers and businesses or through the Judiciary in the general judicial environment.

As of 2018, the Supreme Court has published 668 consumer protection rulings. Regarding motor credit agreements, the Supreme Court has consistently ruled that motor credit agreements are positioned as ordinary agreements. The parties in dispute should take their case to the general Judiciary (the relevant District

\footnotetext{
${ }^{2}$ Kunthi Fahmar Shandy, 'Inflasi Rendah, Konsumen Masih Menunda Belanja' (Sindonews, 2020) <https://ekbis.sindonews.com/read/121802/33/inflasi-rendah-konsumen-masih-menundabelanja-1596463712> accessed 10 August 2020.

3 B Sravanthi, 'Consumer Protection Rights In India: Problems \& Practices' (2020) 9 International Journal Of Multidisciplinary Educational Research.
} 
Court) ${ }^{4}$ to affirming the competence of the general Judiciary in motor vehicle credit agreement disputes, the Supreme Court's rulings make corrections to the authority of the Consumer Dispute Resolution Agency (BPSK). The consistency of the Supreme Court justices can be good news for financing companies. However, on the other hand, it becomes unsettling news for consumers who dispute their disputes through BPSK. ${ }^{5}$

Based on the above background, the problems that can be raised in this paper are as follows:

1. How is the resolution of consumer disputes from the perspective of Law No. 8 of 1999 on Consumer Protection?

2. How is the role of the General Judiciary and the Consumer Dispute Resolution Agency inefficient settlement of consumer disputes based on the principle of lex specialis derogate legi general?

This research uses Posner efficiency theory to analyze the problems that occur. Posner's opinion analyzes the perspective of economic efficiency with Pareto efficiency criteria, namely " that a situation is efficiency-enhancing if at least one person can be made better off without making anyone else worse off." More Posner also added, "a legal change is efficiency-enhancing if the gains to the winners exceed the losses to the loser, and thus, the winners could, hypothetically, compensate the losers for their losses and still be a better off."

The principle of lex specialis derogat legi generalis (special law (lex specialis) overrides the general LawLaw (lex generalis), namely: first, the provisions found

4 Muhammad Yasin, 'Palu Hakim Konsisten Koreksi Kewenangan BPSK: Sengketa Antara Konsumen Dengan Pelaku Usaha Dalam Perjanjian Kredit Motor Diputuskan Sebagai Kewenangan Absolute Peradilan Umum. Quo Vadis BPSK?' (Hukum Online, 2018) <https://www.hukumonline. $\mathrm{com} / \mathrm{berita} / \mathrm{baca} / \mathrm{lt5a} 8 \mathrm{~d} 57180 \mathrm{~b} 266 /$ palu-hakim-konsisten-koreksi-kewenangan-bpsk/> accessed 10 April 2020.

5 Muhammad Yasin, 'Palu Hakim Konsisten Koreksi Kewenangan BPSK: : Sengketa Antara Konsumen Dengan Pelaku Usaha Dalam Perjanjian Kredit Motor Diputuskan Sebagai Kewenangan Absolute Peradilan Umum. Quo Vadis BPSK?' (Hukum Online, 2018) <https://www.hukumonline. $\mathrm{com} /$ berita/baca/lt5a8d57180b266/palu-hakim-konsisten-koreksi-kewenangan-bpsk?page=2> accessed 10 April 2020. 
in the general rule of law remain in effect, except those specifically stipulated in the special rule of law. Second, the provisions of lex specialis must be equivalent to lex general (Law by Law). Third, the provisions of lex specialis must be in the same legal environment (regime) as lex generalists.

This research is a type of normative legal research that is prescriptive with a statue approach. The types and data sources used are primary legal materials obtained from the Constitution 1945, Law No. 8 of 1999 on Consumer Protection, and other relevant laws and regulations, including Regulation of the Minister of Industry and Trade No. 350/MPP. Kep/12/2001 on the Implementation of Duties and Authority of BPSK, Regulation of the Minister of Trade (Permendag)No. 06 of 2017 on BPSK. Secondary legal materials were obtained from books, literature, official documents, scientific works, and experts' legal journals. The data analysis method used in this study is qualitative.

\section{Judicial System in Indonesia}

In the theory of separation of powers, Montesquieu is best known for the teachings of the Triassic Politika (separation of state powers into three): executive (law enforcement), the legislature (lawmaker), and judiciary or judiciary (supervisor of the implementation of the LawLaw). One of the elements to create or restore balance in the public order is by law enforcement or a free/independent judiciary, fair and consistent in its implementation or applying existing laws and in the face of violation of the LawLaw by an independent body that is the court. ${ }^{6}$

A court is the official body or institution of a country, the holder of judicial powers that carries out the judicial system to examine, prosecute, and dismiss cases. At the same time, the Judiciary is a process carried out in a court that deals with the task of examining, dissingenating, and prosecuting cases. The Indonesian Constitution divides this Judiciary's power into five areas of the Judiciary, namely the general Judiciary, the religious Judiciary, the state administrative court, the

${ }^{6}$ Sudikno Mertokusumo, 'Sistem Peradilan Di Indonesia' (1997) 6 Jurnal Hukum Ius Quai Iustum.[1]. 
military Judiciary, and the constitutional Judiciary. ${ }^{7}$

In Indonesia, there are several judicial bodies as stipulated in Article 25 of Law No. 48 of 2009 on Judicial Powers stating: ${ }^{-}$

(1) Judicial bodies under the Supreme Court include judicial bodies in the general judicial environment, religious Judiciary, military Judiciary, and state administrative courts.

(2) As referred to in paragraph (1), the general Judiciary shall be authorized to examine, prosecute, and dismiss criminal and civil cases by the provisions of the laws and regulations.

(3) As referred to in paragraph (1), the religious Judiciary shall be authorized to examine, prosecute, break, and resolve cases between people who are Muslims by the provisions of the laws and regulations.

(4) As referred to in paragraph (1), the military Judiciary shall be authorized to examine, prosecute, and break military criminal cases by the provisions of the laws and regulations.

(5) As referred to in paragraph (1), the administrative Judiciary of the state shall be authorized to examine, prosecute, disconnect, and resolve state administrative disputes by the provisions of the laws and regulations.

In addition to the above judicial body, the LawLaw also governs the subject matter of a special judicial body, as stated in article 27, paragraph 1, which reads, "A special court can only be established in one of the judicial environments under the Supreme Court as referred to in Article 25". Thus, in any judicial environment under the Supreme Court, a special court can still be established to examine, prosecute, and dismiss certain cases.

\footnotetext{
${ }^{7}$ Normand Edwin Elnizar, 'Bingung Mau Berperkara? Mari Kenali Jenis-Jenis Pengadilan Di Indonesia' (Hukum Online, 2018) < https://www.hukumonline.com/berita/baca/lt5b4f09b41a4e1/ bingung-mau-berperkara-mari-kenali-jenis-jenis-pengadilan-di-indonesia?page $=2>$ accessed 10 May 2020. Kehakiman.

${ }^{8}$ Undang-Undang Republik Indonesia Nomor 48 Tahun 2009 Tentang Kekuasaan
} 
The characteristic of a special court, according to Dian Rositawati, is the LawLaw of events (litigation procedures and trials) that differ from each other. Besides, the arrangements in the LawLaw are explicitly individual as special courts, most of which have ad hoc judges. ${ }^{9}$ are some special courts:

1. Special courts in the general judicial environment: Children's Court (criminal LawLaw), Corruption Criminal Court (criminal LawLaw), Fisheries Court (criminal law field), Human rights court (criminal law field), Commercial Court (civil LawLaw), Industrial Relations Court (civil law field).

2. The special court in the religious judicial environment: Special in Nanggroe Aceh Darussalam Province, the religious court with Syar'iyah Court and religious high court with the name of Aceh Syar'iyah Court. His authority is also more based on the mandate of special autonomy. There are additional authorities related to Islamic worship and broadcasting in Aceh.

3. A special court under the state administrative, judicial environment, namely the Tax Tribunal.

4. The constitutional court handles the test of the conformity of the content of the LawLaw with the Indonesian constitution, namely the 1945 Constitution held in the Constitutional Court. There is also another authority for the Constitutional Court, which is directly regulated in the 1945 Constitution.

In addition to these courts, some institutions are "adjudicating" but are not referred to as quasi-courts. Prof Jimmy Asshidiqie introduced the term Judicial Quasi-Institute in a paper entitled Special Court published on his website. Heargued that in an era of reform, developed judicial powers, in addition to special courts, also developed quasi-court or semi-court institutions. Quasi-court terms are institutions that have the authority to prosecute and dismiss a case but are not courts.

9 Normand Edwin Elnizar, 'Bingung Mau Berperkara? Mari Kenali Jenis-Jenis Pengadilan Di Indonesia' (Hukum Online, 2018) <https://www.hukumonline.com/berita/baca/lt5b4f09b41a4e1/ bingung-mau-berperkara-mari-kenali-jenis-jenis-pengadilan-di-indonesia?page $=4 />$ accessed 10 May 2020. 
In the foreword to the book "White Black Special Prosecution", published by the Judicial Commission, Prof. Jimmy Asshiddiqie said that these institutions, in addition to adjudicating, often have mixed with regulatory and/or administrative functions. Some of them are in the form of state commissions; some use the term agency or board. For example, the Consumer Dispute Resolution Agency (BPSK), the Business Competition Supervisory Commission (KPPU), the Indonesian Broadcasting Commission (KPI), the Electoral Supervisory Board (Bawaslu), the Ombudsman of the Republic of Indonesia (ORI), the Court of Shipping and others. ${ }^{10}$

\section{Consumer Dispute Resolution Agency as Judicial Quasi}

The 1945 Constitution has undergone several amendments that spawned various major state institutions and supporters of governance. Among others in the Judicial, the constitutional court as the state institution of judicial power and the Supreme Court, then judicial commission as organ supporting with the main task of proposing the nominee of the chief justice and maintaining the dignity and dignity of judges. In addition to the two institutions, some institutions perform semi-judicial functions whose birth is not mentioned in the 1945 Constitution but formed through the LawLaw. This is given the existence of quasi-judicial institutions in the new constitution recognized in the fourth amendment of the NRI Constitution passed in the Annual Session of the MPR 2002, dated 1-11 August 2002. This recognition is stipulated in article 24 paragraph (3) of the NRI Constitution 1945, which states that "Other bodies whose functions pertain to judicial power are governed by law".

The Judicial Quasi Institution arrangement is increasingly strongly regulated in Law No. 48 of 2009 on judicial powers. Article 38 paragraph (1) specifies that "In addition to the Supreme Court and the judicial bodies under it and the Constitutional Court, there are other bodies whose functions relate to judicial power." In the provisions of Article 38, paragraph (2) further regulate the limitations 
of functions relating to judicial power, including a). investigation and investigation, b). the prosecution, c). execution of the award, d). provision of legal services, and, e). settlement of disputes outside the courts. Furthermore, Article 38 paragraph (3) stipulates that law governs provisions concerning other bodies whose functions relate to judicial power.

These institutions are the Consumer Dispute Resolution Agency (BPSK), the Business Competition Supervisory Commission (KPPU), the Ombudsman of the Republic of Indonesia. The three institutions have the same function and authority as the court because it has the authority to dismiss the case, and the verdict has the power as the court's ruling. ${ }^{11}$

Article 49 paragraph (1) of Law No. 8 of 1999 on Consumer Protection has given birth to the Consumer Dispute Resolution Agency (BPSK), a judicial quasiinstitution. The institution is authorized to examine, resolve and resolve a dispute or case of violation of the law and a particular ethical violation; the decision is final and binding, as is the verdict of the "inkracht". ${ }^{2}$ However, some BPSK rulings cannot be implemented(nonexecutable)because they must be strengthened until the Supreme Court to execute the verdict.

\section{Consumer Dispute Resolution}

Businesses tend to choose a standard agreement model unilaterally determined that narrows the bargaining space to consumers. The default clause has the potential to harm the rights of consumers, as consumers cannot cancel the agreement if the business performs a default. Law No. 8 of 1999 on Consumer Protection strictly governs the standard clause. Businesses should protect consumers because of businesses and consumers. There has been a contractual relationship that requires that the business person be held accountable in the event of default by the principle

\footnotetext{
${ }^{11}$ Muhammad Risnain, 'Eksistensi Lembaga Quasi Judisial Dalam Sistem Kekuasaan Kehakiman Di Indonesia: Kajian Terhadap Komisi Pengawas Persaingan Usaha' (2014) 3 Jurnal Hukum dan Peradilan.[49-50].

${ }^{12}$ Rahmi Rimanda, 'Keberadaan Badan Penyelesaian Sengketa Konsumen (BPSK) Sebagai Lembaga Quasi Yudisial Di Indonesia’ (2019) 4 Jurnal Bina Mulia Hukum.[20].
} 
of the privity of contract; the contractual relationship then there is a responsibility. ${ }^{13}$

In the event of loss to consumers, it is not separated from the responsibility of the business person as mentioned in Article 19 paragraph UUPK states that the business person is responsible for providing compensation for damages, pollution, and/or losses of consumers due to consumer goods and/or services produced or exchanged. Furthermore, Article 19 paragraph (2) states that compensation, as referred to in paragraph (1), maybe in the form of refund or replacement of goods and/or services of similar or equivalent value, or health care and/or compensation by the provisions of applicable laws and regulations.

Consumer protection laws provide two kinds of space for consumer dispute resolution, namely dispute resolution through litigation and settlement of consumer disputes (nonlitigation) as Article 45 paragraph (1) UUPK stipulates that any aggrieved consumer can sue a business through an institution tasked with resolving disputes between consumers and businesses or through the Judiciary located in the general judicial environment. As for paragraph (4) stating that it is chosen to resolve consumer disputes out of court, a lawsuit through the courts can only be pursued if such attempts are declared unsuccessful by either party or the parties.

\section{Settlement of Consumer Disputes by the Consumer Dispute Resolution Agency (BPSK)}

According to Prof Adi Sulistiyono, ${ }^{14}$ Dispute resolution through nonlitigation pathways is not a panacea that can resolve all disputes, but by using this path, some advantages can be obtained, namely:

1. To reduce congestion and court congestion in court. The number of cases brought to court causes litigation to be often prolonged and costly and often yields unsatisfactory results;

2. To increase community engagement (decentralization of the LawLaw) or

\footnotetext{
${ }^{13}$ Desy Ary Setyawati, 'Perlindungan Bagi Hak Konsumen Dan Tanggung Jawab Pelaku Usaha Dalam Perjanjian Transaksi Elektronik' (2017) 1 Syiahkuala Law Journal.[44].

${ }^{14}$ Adi Sulistiyono, 'Merasionalkan Budaya Musyawarah Untuk Mengembangkan Penggunaan Penyelesaian Sengketa Win-Win Solution', Orasi Ilmiah Dalam Dies Natalis XXIX Universitas Sebelas Maret Tanggal 12 Maret 2005 (2005).
} 
empower the parties in dispute resolution;

3. To facilitate the path of justice (acces to justice) in the community;

4. To provide an opportunity for the achievement of dispute resolution resulting in a decision acceptable to all parties. So the parties do not pursue appeals and cassation;

5. Settlement of things faster and cheaper cost;

6. Confidential;

7. Higher levels of possibility to implement the agreement so that the disputed parties' relationship in the future is still possible well established;

8. Reduce the outbreak of "foul play" in the courts.

BPSK is an official institution established by the government to help consumers and businesses resolve consumer disputes through nonlitigation lines. Normatively, this institution's authority is already stipulated in Article 52 of the Consumer Protection Act and further outlined its dispute resolution mechanism stipulated in Regulation of the Minister of Industry and Trade No. 350/MPP. Kep/12/2001 on the Implementation of Duties and Authority of BPSK continued with regulating the Minister of Trade (Permendag)No. 06 of 2017 on BPSK.

Based on Article 52 of the UUPK, the duties and authorities in BPSK are as follows:

1. carry out the handling and resolution of consumer disputes, using mediation or arbitration or conciliation;

2. provide consumer protection consultation;

3. supervise the inclusion of standard clauses;

4. report to the general investigator in the event of a violation of the provisions of this LawLaw;

5. receive complaints, both written and unwritten, from consumers about violations of consumer protection;

6. conduct research and examination of consumer protection disputes;

7. call businesses suspected of breaching consumer protection;

8. call and present witnesses, expert witnesses and/or anyone deemed to be aware of violations of this LawLaw;

9. request the help of investigators to present business actors, witnesses, expert witnesses, or everyone as referred to in the letters $g$ and letter $h$, who are not willing to fulfill the call of the consumer dispute resolution agency;

10. obtain, research, and/or assess letters, documents, or other evidence tools for investigation and/or examination;

11. decide and determine whether or not there is any loss on the consumer's side;

12. notify the verdict to the business actor who has violated consumer protection;

13. to impose administrative sanctions on business actors who violate the provisions of this LawLaw. 
BPSK is obliged to issue a decision no later than 21 working days after the lawsuit is received. Within no later than 7 working days after receiving the BPSK decision, business actors must implement the decision. The parties can submit objections to the District Court no later than 14 working days after receiving the decision's notification. Business actors who do not raise objections are deemed to have accepted the BPSK decision. If a business actor does not carry it out, BPSK will submit the investigator's decision to investigate the applicable laws' provisions.

Regarding the BPSK decision, a decision on the execution is requested to the District Court at the injured consumer. In the case of an objection to a BPSK decision, the District Court is obliged to issue a decision no later than 21 days after the objection is received. Upon this decision, the parties can submit an appeal to the Supreme Court of the Republic of Indonesia within no later than 14 days and must issue a decision no later than 30 days after receiving the appeal.

For comparison, in India, the Consumer Protection Act provides three levels for redressal consumer complaints consisting of District Consumer Disputes Redressal Forums (DCDRF), State Consumer Disputes Redressal Commission (SCDRC), National Consumer Disputes Redressal Commission (NCDRC). Dispute resolution through the three levels is based on the disputed value; DCDRF handles disputes with values below 20 lakh ( 2 million rupees; approx Rp. 400 million), SCDRC handles cases ranging from 20 lakh to 1 crore $(2$ million rupees to 10 million rupees; Rp. 2 billion) and the NCDRC handle cases over 1 crore (10 million rupees). If you do not accept the decision, you can appeal the following order; appeal against the DCDRF decision to the SDCRD, appeal against the SDCRD decision to the NSCDC, while appealing to the NCDRC to the Supreme Court. All appeals must be filed within 30 days of filing and will be filed accompanied by an official copy of the order. The 30 day period counts not from the date of order but from the date the order is communicated to the appellant. Parties who fail or do not comply with the orders of the DCDRF, SDCRD to the NSCDC will be sentenced to imprisonment for a period of not less than one month but extendable to three 
years, or with a fine of not less than two thousand rupees but which can be up to ten thousand rupees or both. ${ }^{15}$

The Tribunal for Consumer Claims of Malaysia (TCC) as a quasi-judicial is an independent body established under the Consumer Protection Act 1999 (CPA 1999) with the main function of hearing and determining consumers' claims. TCC is an alternative dispute resolution (ADR) born to overcome weaknesses in the court system. Establishing TCC aims to provide an alternative channel for consumers seeking compensation to merchants/suppliers of goods and services in a simple, cheap, and fast way. This quasi-judicial body's main feature is that consumers can file claims without going through lengthy and complicated legal proceedings, at a reasonable fee of RM5.00 to submit their claim and claims will be heard and decided within 60 days from the commencement date of the trial. TCC can assist the parties to negotiate an agreed settlement related to a claim. Where the party has reached an agreed settlement, TTC will approve and record the settlement; however, if the TCC is found to be unsuitable to assist the parties to negotiate an agreed settlement related to the claim, or the parties cannot reach an agreed settlement related to the claim, The TCC will continue to determine the dispute. During the trial of the claim at TCC, the Session Chairperson will assist the parties regarding the plaintiffs' disputed issues. An important feature of the TCC is that the Chairperson of the Assembly is empowered to initiate an alternative dispute resolution (ADR) process by negotiation. Negotiation is a discussion and mutual understanding of the terms of a transaction or agreement. Negotiations between the parties are carried out without assistance from the referee or consultants. Dealers/manufacturers/ suppliers of services or goods are more dominant in the negotiation process. The imbalance of bargaining power, lack of or low level of legal understanding and literacy, awareness of consumer rights is one of the causes of consumer rights not well protected. After the discussion is over, the case will be summoned before the session's Chairperson to be informed whether the settlement has been reached or

\footnotetext{
15 B Sravanthi (n 3).
} 
otherwise. If a settlement has been reached, the Assembly's Chairperson will record the settlement by issuing an Award by Consent. If the negotiations fail, then the trial will continue, and the Chairperson of the session will make a decision based on the feasibility and facts submitted by the parties. The Chairperson's decision will be recorded through the Post-Trial Award. ${ }^{16}$

ADR with its win-win solution is in line with Posner's opinion, which analyzes the perspective of economic efficiency with Pareto efficiency criteria, namely "that a situation is efficiency-enhancing if at least one person can be made better off without making anyone else worse off," which means that a situation, in which there is efficiency, at least one person can be made better, without making someone else worse. Posner further adds, "a legal change is efficiency-enhancing if the gains to the winners exceed the losses to the loser, and thus, the winners could, hypothetically, compensate the losers for their losses and still be better off' that is, changes to the LawLaw will increase efficiency if the profit for the winning party exceeds the loss for the losing party, and then the winning party can compensate the losing party so that the losing party remains better. ${ }^{17}$

\section{Lex Specialis Derogat Legi Generalis}

Laws that have been codified in law often act as positive LawLaw having a conflict of norms or conflicts with other laws. The function of legal principles in LawLaw can validate and have a normative and binding effect on the parties. It is binding because its existence is based on the formulation of the legislators and judges. ${ }^{18}$

Several things must be considered in the principle of lex specialis derogat legi generalis (special laws (lex specialis) overriding general laws (lex generalis),

\footnotetext{
${ }^{16}$ Rahman Ismail, 'Zamami Osman Alternative Dispute Resolution Process In The Tribunal For Consumer Claims Of Malaysia; A Way Forward' (2019) 9 International Journal Of Asian Social Science.[345].

${ }^{17}$ Revina Aprilia Dewantari and Munawar Kholil, 'Penerapan Teori Efisiensi Dalam Pedekatan Rule of Reason Pada Pembuktian Kasus Persaingan Usaha Tidak Sehat' (2018) VI Privat Law.

${ }^{18}$ Budiman Fikri, 'Penerapan Asas Lex Specialis Derogat Legi Generalis Dan Penyelesaian Sengketa Ekonomi Dalam Undang-Undang Perbankan Syariah Di Indonesia’ (2017) 12 Jurnal AlHikam.[158].
} 
namely: first, the provisions found in general legal rules remain valid, except those that are specifically regulated in special legal rules. Second, the provisions of the lex specialis must be equal to the provisions of the lex general (Law with Law). Third, the lex specialis must be in the same legal environment (regime) as lex generalis. ${ }^{19}$ Regarding these matters, it can be explained.

According to Prof. Subekti, S.H. Civil law, in a broad sense, includes all material private LawLaw, namely all basic laws governing individual interests. ${ }^{20}$ Civil law, which is regulated in the Civil Code (KUHPer), includes, among others, regulates general engagement, which is born either by LawLaw or by agreement KUHPer is a lex generalist. Referring to Article 7 paragraph (1) of Law Number 12 of 2011 on the Establishment of Legislative Regulations ("Law 12/2011”) as amended by Law No. 15 of 2019 on Amendments to Law Number 12 of 2011 on the Establishment of Legislative Regulations ("Law 15/2019") which reads: The type and hierarchy of Legislative Regulations consist of: (a) Constitution of the Republic of Indonesia in 1945; (b) Ruling of the People's Consultative Assembly; ( c) Government Laws/Regulations Substituting Laws; (d) Government Regulations; (e) Presidential Regulations; (f) Provincial Regional Regulations; and (g) Regency/ City Regional Regulations. The 1945 Constitution Transition states: “All existing state bodies and regulations are still in force, as long as no new one has been established under this Constitution." Therefore, KUHPer as a Law until now still applies in Indonesia, as long as a new law has not replaced it. Thus, KUHPer has the same degree or hierarchy as Law No. 8 of 1999 on Consumer Protection.

Provisions in Law No. 8 of 1999 on Consumer Protection are within the legal framework of Civil Law (KUHPer); the LawLaw was specifically formed to create a balance of protection of consumers and business actors' interests that a healthy economy is created. Consumers and business actors are often bound by agreements that use the Standard Clause of the agreement so that this LawLaw regulates the Standard Clause and its oversight by BPSK; therefore, this LawLaw meets the criteria

\footnotetext{
19 Bagir Manan, Hukum Positif Indonesia: Satu Kajian Teoritik (UII Press 2004).[54].

${ }^{20}$ Subekti, Pokok-Pokok Hukum Perdata (PT Intermasa 2003).[9].
} 
as a lex specialis. UUPK is also a provision lex specialis of the Civil Procedure Law Book, wherein the submission of consumer lawsuits filed by consumers is filed in place of consumer position, not in the position of business actors (defendant). Besides, in the case of consumer lawsuits, what must prove the error element is the business perpetrator's burden and not on the consumer (plaintiff). ${ }^{21}$

\section{The annexation of the General Court of the Consumer Dispute Resolution Agency}

Consumer protection law is the general principles and rules that regulate and protect consumers in the relationship and problems of providing and using consumer products (goods and/or services) between providers and users in social life. ${ }^{22}$ Legal protection in consumer protection law is state interference to protect individual consumers from unfair business practices. ${ }^{23}$

The consistency of the Supreme Court since 2013 in resolving consumer disputes such as motorized credit agreements, which are positioned as ordinary agreements (even though the parties use the term consumer financing in their agreements) and state that the disputing parties should bring their cases to the general court (the competent District Court) ${ }^{24}$ makes the opportunity to bring disputes over motor vehicle loan agreements to BPSK even thinner.

In addition to affirming the general court's competence in motor vehicle loan agreement disputes, the Supreme Court decisions make corrections to the authority of the Consumer Dispute Resolution Agency (BPSK). Based on Law no. 8 of 1999 concerning Consumer Protection, BPSK is an agency responsible for handling and resolving disputes between business actors and consumers. This LawLaw provides space for every consumer who feels aggrieved to sue business actors through an institution tasked with resolving consumer and business actor disputes or through

\footnotetext{
${ }^{21}$ Agus Suwandono, 'Ruang Lingkup Hukum Perlindungan Konsumen', Modul Hukum Perlindungan Konsumen (Repository UT).[9].

${ }_{22}$ Az Nasution, Hukum Perlindungan Konsumen : Suatu Pengantar (Diadit Media 2011).[37].

${ }^{23}$ Yusuf Shofie, Perlindungan Konsumen Dan Instrumen-Instrumen Hukumnya (Citra Aditya Bakti 2011).[52-53].

${ }^{24}$ Muhammad Yasin (n 5).
} 
courts located within the general court. In one of the cases that occurred in Malang, for example, consumers expressed objections to a finance company's actions that forcefully pulled a credit car. The act of forced taking without a court order is considered by consumers as an act against the LawLaw, thus bringing the case to the BPSK of Malang City. This case leads to an appeal, and the Supreme Court firmly states that the dispute between the petitioner and the respondent regarding consumer financing has the potential to become default so that it becomes the authority of the general court. Despite the mention of consumer financing agreements, the authority to adjudicate disputes is not in the hands of BPSK but the general court. The consistency of the Supreme Court justices, in this case, is good news for finance companies; on the other hand, it is unpleasant news for consumers who file their disputes through BPSK as well as the annexation of the general court against BPSK.

If you look at the duties and authorities of BPSK, it can be said that BPSK is broader than a civil court body that enters into the duties and powers of the National Consumer Protection Agency (BPKN), which can perform tasks in the field of supervision and consultation. Thus, based on these duties and authorities, there are two strategic functions of BPSK, namely: ${ }^{25}$

a. BPSK functions as a legal instrument for dispute resolution outside the court, namely through conciliation, mediation, arbitration;

b. To supervise the inclusion of standard clauses by business actors. This includes standard clauses in the fields of electricity, telecommunications, banks, finance companies. One of these strategic functions is to create a balance between the interests of business actors and consumers.

Pancasila as a grundnorm teaches deliberation for consensus, the existence of BPSK as an ADR that prioritizes the handling and resolution of consumer disputes, through mediation or arbitration or conciliation as its duties and authorities are contained in Article 52 paragraph (1) of Law No. 8 of 1999 concerning Consumer Protection is a peaceful solution/settlement and a win-win solution to consumer

${ }^{25}$ Erma Rusdiana Murni and Rina Yulianti, 'Karakteristik Kasus Konsumen Dan Faktor Penghambat Pendirian BPSK (Badan Penyelesaian Sengketa Konsumen' (2016) 5 Yustisia.[16]. 
disputes with producers. With a task like this, BPSK can immediately issue its decision to end consumer disputes. It is hoped that with simple and short dispute resolution, dispute resolution through courts that tend to be long and convoluted is no longer necessary ${ }^{26}$ as a form of the annexation of the General Courts on the duties and powers of BPSK.

\section{Conclusion}

Based on Law No. 8 of 1999 concerning Consumer Protection, consumer dispute resolution can be carried out in two ways: litigation or general and nonlitigation courts, namely through the Consumer Dispute Resolution Agency (BPSK) as quasi-judicial. Settlement of consumer disputes through the courts refers to the provisions of the general court in force while at BPSK using Alternative Dispute Resolution (ADR) through mediation or arbitration or conciliation; BPSK is obliged to issue a decision no later than 21 (twenty-one) working days after the lawsuit is received. The decision of BPSK is requested to determine the execution of the District Court. The parties can submit objections to the District Court and can file an appeal to the Supreme Court.

Since 2013 the Supreme Court has consistently decided consumer disputes in the position of an ordinary agreement, stating that the disputing parties should bring their cases to the general court, also correcting the authority of BPSK; this is the annexation of the general court to BPSK considering that BPSK is a mandate of Law No. 8 of 1999, which is the lex specialis of the Civil Code on consumer protection, which contains regulations regarding standard clauses in the agreement between consumers and business actors so that it cannot be categorized as an ordinary agreement; As an ADR guided by a win-win solution, BPSK is a quasijudicial appointed by LawLaw to resolve consumer disputes in compliance with Article 38 paragraph (1) of Law Number 48 of 2009 concerning Judicial Power so that it is authorized to carry out the functions of judicial power as referred to

\footnotetext{
${ }^{26}$ Janus Sidabalok, Hukum Perlindungan Konsumen Di Indonesia (PT Citra Aditya Bakti 2010).[198].
} 
in Article 38 paragraph (2), namely: a). investigation and investigation, b). the prosecution, c). implementation of the decision, d). provision of legal services, and, e). settlement of disputes outside the court, especially to decide consumer disputes effectively and efficiently.

\section{Bibliography}

Adi Sulistiyono, 'Merasionalkan Budaya Musyawarah Untuk Mengembangkan Penggunaan Penyelesaian Sengketa Win-Win Solution', Orasi Ilmiah Dalam Dies Natalis XXIX Universitas Sebelas Maret Tanggal 12 Maret 2005 (2005).

Agus Suwandono, 'Ruang Lingkup Hukum Perlindungan Konsumen', Modul Hukum Perlindungan Konsumen (Repository UT).

Az Nasution, Hukum Perlindungan Konsumen : Suatu Pengantar (Diadit Media 2011).

B Sravanthi, 'Consumer Protection Rights In India: Problems \& Practices' (2020) 9 International Journal Of Multidisciplinary Educational Research.

Bagir Manan, Hukum Positif Indonesia: Satu Kajian Teoritik(UII Press 2004).

Budiman Fikri, 'Penerapan Asas Lex Specialis Derogat Legi Generalis Dan Penyelesaian Sengketa Ekonomi Dalam Undang-Undang Perbankan Syariah Di Indonesia' (2017) 12 Jurnal Al-Hikam.

Desy Ary Setyawati, 'Perlindungan Bagi Hak Konsumen Dan Tanggung Jawab Pelaku Usaha Dalam Perjanjian Transaksi Elektronik’ (2017) 1 Syiahkuala Law Journal.

Erma Rusdiana Murni and Rina Yulianti, 'Karakteristik Kasus Konsumen Dan Faktor Penghambat Pendirian BPSK (Badan Penyelesaian Sengketa Konsumen' (2016) 5 Yustisia.

Fika Nurul Ulya, 'Ini 10 Negara Jatuh Resesi Akibat Pandemi, Bagaimana Dengan Indonesia?' (Kompas.com, 2020) <https://money.kompas.com/ $\mathrm{read} / 2020 / 08 / 13 / 133706626 /$ ini-10-negara-jatuh-resesi-akibat-pandemibagaimana-dengan-indonesia?page=all $>$ accessed 20 August 2020 .

Janus Sidabalok, Hukum Perlindungan Konsumen Di Indonesia (PT Citra Aditya Bakti 2010).

Kunthi Fahmar Shandy, 'Inflasi Rendah, Konsumen Masih Menunda Belanja' 
(Sindonews, 2020) <https://ekbis.sindonews.com/read/121802/33/inflasirendah-konsumen-masih-menunda-belanja-1596463712> accessed 10 August 2020.

Muhammad Risnain, 'Eksistensi Lembaga Quasi Judisial Dalam Sistem Kekuasaan Kehakiman Di Indonesia: Kajian Terhadap Komisi Pengawas Persaingan Usaha' (2014) 3 Jurnal Hukum dan Peradilan.

Muhammad Yasin, 'Palu Hakim Konsisten Koreksi Kewenangan BPSK: : Sengketa Antara Konsumen Dengan Pelaku Usaha Dalam Perjanjian Kredit Motor Diputuskan Sebagai Kewenangan Absolute Peradilan Umum. Quo Vadis BPSK?' (Hukum Online, 2018) <https://www.hukumonline.com/ berita/baca/lt5a8d57180b266/palu-hakim-konsisten-koreksi-kewenanganbpsk?page $=2>$ accessed 10 April 2020 .

—_, 'Palu Hakim Konsisten Koreksi Kewenangan BPSK: Sengketa Antara Konsumen Dengan Pelaku Usaha Dalam Perjanjian Kredit Motor Diputuskan Sebagai Kewenangan Absolute Peradilan Umum. Quo Vadis BPSK?' (Hukum Online, 2018)<https://www.hukumonline.com/berita/baca/1t5a8d57180b266/ palu-hakim-konsisten-koreksi-kewenangan-bpsk/> accessed 10 April 2020.

Normand Edwin Elnizar, 'Bingung Mau Berperkara? Mari Kenali Jenis-Jenis Pengadilan Di Indonesia' (Hukum Online, 2018) <https://www.hukumonline. $\mathrm{com} /$ berita/baca/lt5b4f09b41a4e1/bingung-mau-berperkara-mari-kenalijenis-jenis-pengadilan-di-indonesia?page $=2>$ accessed 10 May 2020 .

_- 'Bingung Mau Berperkara? Mari Kenali Jenis-Jenis Pengadilan Di Indonesia' (Hukum Online, 2018) <https://www.hukumonline.com/berita/ baca/lt5b4f09b41a4e1/bingung-mau-berperkara-mari-kenali-jenis-jenispengadilan-di-indonesia?page=4/> accessed 10 May 2020 .

Rahman Ismail, 'Zamami Osman Alternative Dispute Resolution Process In The Tribunal For Consumer Claims Of Malaysia; A Way Forward' (2019) 9 International Journal Of Asian Social Science.

Rahmi Rimanda, 'Keberadaan Badan Penyelesaian Sengketa Konsumen (BPSK) Sebagai Lembaga Quasi Yudisial Di Indonesia' (2019) 4 Jurnal Bina Mulia Hukum.

Revina Aprilia Dewantari and Munawar Kholil, 'Penerapan Teori Efisiensi Dalam Pedekatan Rule of Reason Pada Pembuktian Kasus Persaingan Usaha Tidak Sehat' (2018) VI Privat Law.

Subekti, Pokok-Pokok Hukum Perdata (PT Intermasa 2003). 
Sudikno Mertokusumo, 'Sistem Peradilan Di Indonesia' (1997) 6 Jurnal Hukum Ius Quai Iustum.

Yusuf Shofie, Perlindungan Konsumen Dan Instrumen-Instrumen Hukumnya (Citra Aditya Bakti 2011).

Undang-Undang Republik Indonesia Nomor 48 Tahun 2009 Tentang Kekuasaan Kehakiman.

HOW TO CITE: Otih Handayani, Agus Riwanto and Panti Rahayu, 'The Annexation of The General Judiciary Against Consumer Dispute Resolution Agency' (2021) 36 Yuridika. 